\title{
下肢手術を行った地域在住高齢者の組織硬度と 転倒リスクの関連性
}

\author{
The Relationship between Tissue Hardness and the Fall Risk \\ of the Community-dwelling Elderly after Lower Limb Surgery
}

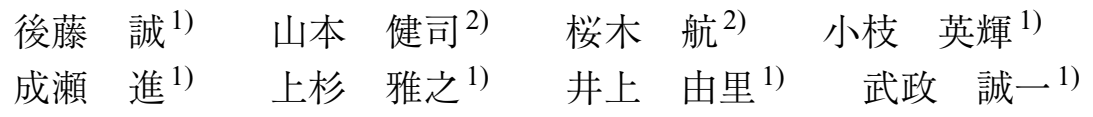

MAKoto GOTO, RPT, PhD $^{1)}$, KENJI YAMAMOTO, RPT ${ }^{2)}$, WAtARU SAKURAGI, RPT ${ }^{2)}$, Hideki KOEDA, RPT, PhD ${ }^{1)}$, Susumu NARUSE, RPT, $\mathrm{PhD}^{1)}$, MASAYUKI UESUGI, RPT, $\mathrm{PhD}^{1)}$, YURI INOUE, RPT, MS ${ }^{1)}$, SEIICHI TAKEMASA, RPT, PhD ${ }^{1)}$

${ }^{1)}$ Department of Physical Therapy, Faculty of Rehabilitation, Kobe International University: 9-1-6 Koyocho-naka, Higashinadaku, Kobe-shi, Hyogo 658-0032, Japan Tel +81 78-940-4115 E-mail: gotou@kobe-kiu.ac.jp

${ }^{2)}$ Suzuki Orthopaedic Hospital

Rigakuryoho Kagaku 31(3): 419-422, 2016. Submitted Dec. 7, 2015. Accepted Jan. 22, 2016.

ABSTRACT: [Purpose] The purpose of this study was to determine the relationship between crural tissue hardness and the frequency of falls in community-dwelling elderly outpatients who visited hospital following lower limb surgery. [Subjects] The subjects of the study were 22 elderly persons. [Methods] Posterior crural tissue hardness was measured using a tissue hardness meter. The results of the operated and the non-operated sides were compared. Subjects' history of falls, walking speed, use of gait-assistive devices, structural deformities of the back, and drug use were also investigated using a fall risk index. [Results] The comparison of the operated and non-operated sides indicated significant differences in crural tissue hardness when subjects' ankles were in maximal dorsiflexion. No significant differences were observed when their ankles were in plantarflexion of $0^{\circ}$. Furthermore, according to the fall risk index, the subjects' propensity for falls increased with age. [Conclusion] The differences in muscle function between the operated and non-operated sides when the ankles are in dorsiflexion may lead to falls in the daily lives of community-dwelling elderly individuals. This suggests that the elderly should perform functional compensatory movements.

Key words: tissue hardness, fall risk, community-dwelling elderly

要旨：〔目的〕片側下肢に関する手術を受け，外来通院しながら日常生活を送っている地域在住高齢者の下腿組織硬 度を把握し, これと, 転倒リスクとの関係を知ることとした。〔対象〕整形外科に通院する地域在住高齢者 22 名と した。〔方法〕組織硬度計にて測定された下腿後面の組織硬度を，手術側と非手術側の 2 群間で比較し，過去の転倒 歴，歩行速度，杖の使用，背部変形，服薬状況からなる Fall Risk Index の調査結果と検討した.〔結果〕足関節最大 背屈位における手術側と非手術側の下腿組織硬度間に有意差が認められたが, 足関節底背屈 0 ○では認められなかっ た。また，高齢ほど転倒頻度が高い傾向が認められた。〔結語〕地域在住高齢者の日常生活において，足関節が背屈 になる状況では手術側と非手術側の筋機能発揮に差が生じ転倒する可能性があり, 機能的代償動作を行っていること が示唆される.

キーワード : 組織硬度, 転倒リスク, 地域在住高齢者

\footnotetext{
1) 神戸国際大学 リハビリテーション学部 理学療法学科:神戸市東灘区向洋町中9丁目 1-6（テ 658-0032) TEL 078-940-4115

2) 鈴木整形外科 


\section{I.はじめに}

平成 25 年国民基礎生活調査によると, 介護が必要と なった主な原因は脑血管疾患 (脳卒中), 認知症, 高齢 による衰弱の順だが, 要支援者ではこれが関節疾患, 高 齢による衰弱, 骨折・転倒の順となる ${ }^{11}$ ，近年，整形外 科学領域に扔いては，ロコモーティブシンドローム，フ レイルといった概念が浸透してきている中で, 下肢の骨 折, 股・膝関節の人工関節手術など運動器の障害に加齢 が伴い生じる運動器機能不全といった移動能力や気力の 低下が懸念されている，併存する疾患が増悪し，意欲・ 体力・気力の消耗が加速することで, 易転倒, 自立生活 困難へと繋がる可能性がある。しかし，筋力低下やバラ ンス能力の欠如, 歩行・移動障害など身体の危険因子に 対し, 適切な時期に運動介入することで, 健康状態を維 持し機能低下に陥る時期を遅らせることも知られている。

臨床では身体能力を評価する様々な試みが行われてい る中で, 生体組織の硬さの違いや筋萎縮などの異常の有 無を触診により確認することが行われている。ただ，こ の触診による硬さの并別は客観的に示すことが難しいこ とから, 組織硬度計などの装置を用いて生体の反発力ゃ 押し込み距離との関係などから客観的に数值化するため の検討がなされているが, 臨床にて組織硬度計を用いた 研究はまだまだ少ない 2-4)。 また，筋硬度に関する報告 には，筋の最大収縮時の硬度を測定したものや定量化を 求めたものがあるが, 安静時や伸張時を検討したものは やはり少ない 5-7). 筋の収縮能力が低下している中高年 者や運動効果を効率的に引き出すことが困難な高齢者で は, 組織の硬化度が低下, もしくはもともと低いとの印 象がある。

そこで今回, 片側下肢に関する手術を受け外来通院し ながら日常生活を送っている地域在住高齢者の下腿組織 硬度について調査し, 転倒リスクとの関倸を知ることを 目的とする。

\section{II. 対象と方法}

\section{1. 対象}

本研究の対象者は, 2004 年以降, 片側下肢のみに手 術 (人工股関節置換術, 人工膝関節置換術, 高位脛骨骨 切り術など）を施行され，外来通院しながら自立した生 活を送っている地域在住者 22 名（男性 5 名, 女性 17 名, 平均年齢 \pm 標準偏差：76.7 \pm 8.03 歳）とした（表 1). 両側に手術を施行された症例, 腹臥位姿勢をとれない症 例, 認知症を有する症例（改定長谷川式簡易知能評価又 ケールにて 20 点未満), 足関節に拘縮を有する症例, 脳 血管疾患など中枢性の重篤な既往のある症例, ペース メーカーを埋め込んだ症例は除外対象とした.

本研究の目的と内容を説明し, 参加は自由でこれを拒
否しても不利益にはならないことを書面と口頭で説明し 承認を得た。また, この結果は学術的研究以外には使用 しないこと，および個人情報保護を厳守することも説明 した後に測定を開始した。

\section{2. 万法}

全対象者の下腿後面の硬さを測定した，測定には組織 硬度計 $(\mathrm{OE}-220$, 伊藤超短波社製 $)$ を使用し, 実験開 始前に測定者には機器による圧迫にて被検者に苦痛を生 じないよう十分練習を行った，検査においては，足背部 をベッド端から出した腹臥位姿勢を開始姿勢とし, 測定 者が同一箇所の測定を行えるよう, 下腿最大周径の高さ で下腿幅の中心に印をつけ測定した ${ }^{8}$ 。 測定肢位は皮 虐・筋などに緊張がない足関節底背屈 $0^{\circ}$ と, 第三者が 他動的に最大背屈し下腿後面が緊張した足関節最大背屈 位の状態とした，組織硬度計は下腿後面に対し垂直に一 回につき $3 \sim 4$ 秒圧迫し, 連続で 3 回行い平均值を測 定值とした。

また，地域在住高齢者に適応できる転倒リスク評価と して, 過去の転倒歴, 歩行速度, 杖の使用, 背部変形, 服薬状況からなる Fall Risk Index（FRI）を使用した。 転倒リスク評価のために必要な検査として今回使用した FRI は, Timed Up and Go テストやファンクショナル リーチテストとの比較的高い相関が認められて㧍り, ADLの評価をするうえで簡便かつ有用であるとされて いる.

分析処理は, 手術側と非手術側の足関節底背屈 $0^{\circ}$ と 最大背屈位に扔ける下腿後面の組織硬度計の值は $\mathrm{t}$ 検定, FRI の結果と組織硬度值については Mann-Whitney の U 検定にて検討した，分析ソフトゥェアは R version 2.8.1.を用い有意水準は $5 \%$ とした。

\section{III. 結 果}

組織硬度計を用いた対象者 22 名の下腿後面の硬さの 平均は, 手術側足関節底背屈 $0^{\circ}$ で $39.5 \mathrm{~N}$, 非手術側足

表 1 対象者特性

\begin{tabular}{lc}
\hline 年齢 $($ 歳 $)$ & $76.7 \pm 8.0$ \\
性別 $($ 人) & 女性 $: 17$, 男性 $: 5$ \\
$\mathrm{BMI}\left(\mathrm{kg} / \mathrm{m}^{2}\right)$ & $22.9 \pm 3.8$ \\
手術後期間 $($ 年 $)$ & $6.1 \pm 3.7$ \\
疾患の内訳人数 $(人)$ & \\
$\quad$ 人工股関節置換術 & 3 \\
$\quad$ 大腿骨䅡部骨折骨接合術 & 6 \\
$\quad$ 人工膝関節置換術 & 8 \\
$\quad$ 高位脛骨骨切り術 & 4 \\
$\quad$ 高原骨折骨接合術 & 1 \\
\hline $\mathrm{n}=22$. 平均值 \pm 標準偏差, または $\mathrm{n}$.
\end{tabular}


関節底背屈 $0 \circ$ で $39.0 \mathrm{~N}$, 手術側足関節最大背屈位で $56.6 \mathrm{~N}$ ， 非手術側足関節最大背屈位で $54.2 \mathrm{~N}$ だった。

手術側と非手術側の間において，最大背屈位における 下腿筋硬度の有意差が認められたが, 底背屈 0 ににおけ る下腿組織硬度の有意な差は認められなかった（表 2)。 FRI を評価したところ, 最小值 4 点, 最大值 7 点, 中央 值は 4 点であった。また, 4 点は 13 名 (平均 72.0 歳), 6 点が 6 名 (平均 81.7 歳), 7 点が 3 名 (平均 86.0 歳) であった。

FRI の結果 4 点 13 名と $6 \cdot 7$ 点 9 名間において下腿組 織硬度の有意差は認められなかったが, 男女間にて非手 術側足関節底背屈 $0^{\circ}$ における下腿組織硬度の有意差が 認められた。

\section{IV. 考 察}

生体軟部組織硬度には, 被検者の筋・皮下組織の粘弾 性，精神的緊張，姿勢，検査直前の運動や身体活動状況， 筋緊張などの要因が影響する ${ }^{9)}$. 組織硬度は垂直圧力に 対し筋によって提供される抵抗力と定義されるが, 筋活 動を反映しているわけではなく, 皮膚や皮下組織ごと押 し込む圧迫力とともに皮下脂肪や筋の硬さを総合的に判 定するものである．深部の筋や垂直圧力を加えにくい部 位は一般的に評価しにくいが, 姿勢保持・歩行などの日 常生活に欠かせない下腿三頭筋を含む下腿後面は，組織 硬度計を正確に操作しうる部位である。肥田ら 10) は組 織硬度測定值が脂肪量の影響を受けているとは考えにく いと述べており，本研究の対象は高齢者であり脂肪量の 影響が少なく，その中に検査時に痛みの訴えや防御性筋 収縮を有する症例は見受けられなかった。

高梨ら 11,12) は軟部組織の弾性值の変化について, 関 節角度変化に伴う筋組織の伸張が大きな影響を与えると 述べており，今回，片側下肢の手術を受け複数年経過し た本研究対象者の足関節の角度を変えた下腿後面の組織 硬度デー夕には意味があったと考えられる。足関節背屈 角度は姿勢評価に有用であり，高齢女性は骨粗鬆症によ る姿勢変化の影響などから足関節背屈角度が少なくなる ことが転倒要因の一つと考察されている，今回，足関節 背屈という下腿三頭筋伸張位において手術側と非手術側 の間に有意な差が認められた。つまり，筋長が長くなる 静止張力に変化があったことを意味している，筋が伸張 位のときは筋膜も伸張され組織硬度が上昇している可能 性があり，膝伸展位という設定から腓腹筋の筋硬度の影 響が大きいのではと考えられる。

組織硬度計の測定自体に明確な基準值はなく，参考值 として内側腓腹筋の筋腹中央部を測定した值（男性は 40.2, 女性 42.7） と比較すると, 本研究での足関節底背 屈 $0^{\circ}$ 結果は低值を示し加齢とともに筋を含めた組織全 体の硬さが軽減していることが分かる。しかし，手術側
表 2 手術側と非手術側の組織硬度比較結果

\begin{tabular}{lcl}
\hline 組織硬度 $(\mathrm{N})$ & 手術側 & \multicolumn{1}{c}{ 非手術側 } \\
\hline 足関節底背屈 $0^{\circ}$ & $39.5 \pm 7.3$ & $39.0 \pm 7.9$ \\
足関節最大背屈位 & $56.6 \pm 8.6$ & $54.2 \pm 9.5^{*}$ \\
\hline
\end{tabular}

平均值 \pm 標準偏差. $*: \mathrm{p}<0.05$.

ではなく非手術側の下腿後面部で男女間に硬さの差が認 められた本研究結果から, 手術側・非手術側の日常生活 での負担のかけ方, 下肢・体幹の変形進行, 姿勢変化な ど地域在住高齢者の下腿筋組織にはさまざまな影響があ ると考えられる. THA 術後患者の場合, 股関節の屈曲・ 伸展角度・筋パワーの減少などがある中で安定した日常 生活を送っているという報告 ${ }^{13)}$ があることから，手術 側と非手術側の下肢との間で代償動作が構築され，転倒 しないよう体全体のバランスを調整していると思われる。

FRI は転倒リスクを評価する簡便なスクリーニング手 段で 14), 今回, カットオフ值 6 点を超えたのは, 22 名 中 6 点が 6 名, 7 点が 3 名であった。 6 点以上の值を示 した高齢者の $28 \%$ が半年以内に転倒しやすい（6 点未 満の場合の転倒頻度は 7\%）とあることから，6 点以上 の 9 名は転倒予防に十分配慮すべきことが分かる．FRI の評価においては過去 1 年の転倒経験への配点が高く, 実際に, 本研究結果からも加齢による身体機能・環境適 応への影響を示唆していた。しかしながら，下腿組織硬 度結果とFRI との密接な関係を得ることはできなかっ たことから，転倒ハイリスク者を発見する手段として組 織硬度計を用いることはないと考えられる.

Tinetti ら 15) は地域高齢者の転倒リスク因子において, 上肢または下肢の筋力低下は転倒の危険率を相対危険率 で $2.2 〜 2.6$ 増大させること, 加齢に伴い絶対的筋量も 低下すること, 特に下半身の筋力低下が認められること を述べている．また，Liら 16) は転倒のほとんどは歩行 中に発生すると述べ, 本研究の対象者となっている地域 在住高齢者は $10 \%$ 弱〜 $20 \%$ 弱の転倒頻度としている. このことから下肢の手術経験のある高齢者らにとって安 全な生活のためには四肢の筋力維持は重要である。しか し, 酒井ら 17) は四肢の筋量減少のみでは必ずしも ADL は低下せず，四肢筋よりも起こりにくい体幹筋量の減少 の可能性を述べており, 付随する疾患, 関節の変形, バ ランス障害などの身体組織変化全体も考慮すべきである。

今回の結果は, 下肢の手術を受け数年経過した地域在 住中高年者における下腿後面の組織硬度は，下腿後面が 伸張位となる足関節背屈位にて手術側と非手術側間で有 意に異なり，また，FRIから高齢ほど転倒リスクが上昇 することを明らかにしたものである，つまり，足関節が 背屈になる状況では手術側と非手術側の筋機能発揮に差 が生じ転倒する可能性があるといえる。しかし, 下腿組 
織硬度とFRI との関係を今回見出すことはできなかっ たことから, 今後さらなる症例数の増加蓄積, さらに 様々な状況での組織硬度の測定デー夕を追加することは， 身体各部位・姿勢・動作などを反映する明確な指標にな りえると考える。

\section{引用文献}

1) 厚生労働省: 平成 25 年国民生活基礎調査の概況. http:// www.mhlw.go.jp/toukei/saikin/hw/k-tyosa/k-tyosa13/d1/16. $h t m l$ (閲覧日 2015年 11 月 22 日)。

2) 中村雅俊, 池添冬芽, 武野陽平・他 : 筋硬度計で測定した 筋のスティフネスと受動的トルクおよび筋の伸張量の関連性. 理学療法学, 2013, 40(3): 193-199.

3) 古後晴基, 黑澤和生, 長谷川敦子・他：筋硬度の定量化な らびに筋硬結に扔ける筋疼痛と筋硬度との関連性. 理学療 法科学, 2010, 25(1): 41-44.

4) Nakamura M, Ikezoe T, Kobayashi T, et al.: Acute effects of static stretching on muscle hardness of the medial gastrocnemius muscle belly in humans: An ultrasonic shearwave elastography study. Ultrasound Med Biol 2014, 40(9): 1991-1997.

5) Akagi R, Takahashi H: Effect of a 5-week static stretching program on hardness of the gastrocnemius muscle. Scand $\mathrm{J}$ Med Sci Sports, 2014, 24(6): 950-957.

6) Akagi R, Takahashi H: Acute effect of static stretching on hardness of the gastrocnemius muscle. Med Sci Sports Exerc, 2013, 45(7): 1348-1354.

7) Gennisson JL, Cornu C, Catheline S: Human muscle hardness assessment during incremental isometric contraction using transient elastography. J Biomech, 2005, 38(7): 1543-1550.

8) Morse CI, Degens H, Seynnes OR, et al.: The acute effect of stretching on the passive stiffness of the human gastrocnemius muscle tendon unit. J Physiol, 2008, 586(1): 97-106.

9) 諸角一記：エビデンスにつなげるための臨床場面で身近 に使える測定法 11一軟部組織硬度の測定法. 理学療法, 2013, 30(3): 363-369.

10) 肥田朋子, 天野幸代：筋硬度計による生体の硬さ測定. 名 古屋学院大学論集, 2010, 46(2): 55-61.

11) 高梨 晃, 川田教平, 塩田琴美・他：軟部組織硬度計を用 いた弾性值評価, 理学療法科学, 2011, 26(5): 667-671.

12) 高梨 晃, 烏野 大, 加藤宗規・他：軟部組織硬度計によ る模擬軟部組織モデル測定時の信頼性の検討. 理学療法科 学, 2009, 24(1): 31-34.

13) Nantel J, Termoz N, Vendittoli PA, et al.: Gait patterns after total hip arthroplasty and surface replacement arthroplasty. Arch Phys Med Rehabil, 2009, 90(3): 463-469.

14) 大河内二郎, 石本恭子, 和田泰三 ·他 : Fall risk index, 高 齢者の転倒予防ガイドライン，鳥羽研二(監), メジカルビュー 社, 東京, 2012, pp2-8.

15) Tinetti ME, Kumar C: The patient who falls: "It's always a trade-off'. JAMA, 2010, 303(3): 258-266.

16) Li W, Keegan TH, Sternfeld B: Outdoor falls among middleaged and older adults: A neglected public health problem. Am J Public Health, 2006, 96(7): 1192-1200.

17) 酒井吉仁, 梅野克身, 荻島久裕・他：静的ストレッチング に抒けるリラクセーションをもたらす伸長感性と筋スティフ ネスの関係. 理学療法科学, 2014, 29(3): 399-403. 